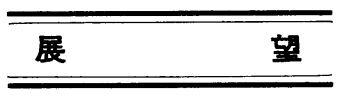

\title{
NBS の精密測定部門の活動
}

朝永 良 夫*

\section{まえがき}

各国とも国立研究機関によつてとの国の計量標準の設 定維持関する研究が行われている。たとえばアメリカ の国立標準局 (National Bureau of Standards略して NBS), イギリスの国立物理研究所 (National Physcial Laboratory 略してNPL), 西独の物理工学研究所 (Physikalisch-Technische Bundesanstalt 略して PTB）等はそれであり，わが国では工業技術院の中央計 量検定所括よび電気試験所がそれに当る。筆者は今回精 密測定機器専門調查団の一員として渡米した際, NBS の 特に精密測定部門の見学をする機会をえた。NBSはアメ リカ商務省に所属する 3000 名余の職員をもつた研究機関 で，広範囲の活動を行つているが，そのうちで精密測定 部門は創立当初よりの伝統的な基礎の上飞立つて地味な 試験研究を続けて招り，民間機関に対する協力指導も非 常に活潑である。以下見聞した所につきその活動の概況 を述べる。

\section{2. 組織と予算}

局長 Allen V.Astin 氏の下に 4 名の次長があり，拉 よそ次のような研究部門に分れている。

電気扣よび電子工学

光学怙よび測定工学

熱. 学

原子物理拉よび放射線物理

化学

機械学

有機招よび繊維材料

冾金学

鉱業製品

建筑工学

応用数学

データ処理法

このはかルコロラド州と無線関係括よび 低温工学に関

* 中央計量検定所, 正会員
する研究所をもつている。

1957年度の予算の概略は, NBS 自身の予算約1000万ド ル飞対して国防省からの予算約 1200万ドル，その他から の予算など約 600 万ドルを加えると 合計約 2800 万ドルと なる。これは邦貨に換算すると約 100 億円である。そし てこれは前年度よりも約 600 万ドル（約22億円）の増と なつている。また 1 人当りの予算は 300 万円をこえる数 字を示している。な和最近は NBS が行う依頼試験の手数 料等の収入はそのまま同所に保留して，これを直接その 試験等に要した 費用にあてることができるようになり， そのような収入年間約 150 万ドルある。1958年度の収 入は表 1 のように見込んでいるという。セメントの試験 は収入全額中非常に大きな 部分を占めていることがうか がわれる。

表 1

\begin{tabular}{|c|c|}
\hline \multicolumn{2}{|c|}{ 1958年度収入見込（ドル） } \\
\hline 標準器 の検叠 & 75 万 \\
\hline 標準製品の譲渡 & 15万 \\
\hline セメントの試 験 & 60 万 \\
\hline その他の製品の試験 & 10万 \\
\hline 合 & 160万 \\
\hline
\end{tabular}

\section{3. 精密測定部門について}

長さ, 角度, ネシ等の精密測定飞関する試験研究を行 つているのは前述組織と怙ける光学抽よび 測定工学部の 中の 2 つ課であつて, 長さ標準の設定維持の仕事もこ こで行われている。すなわちメートル原器 No. 27 が， ア メリカの長さの標準であるメートルを現示する国家原器 として, 副原器 No. 21 , No. 12 招よび No. 4 と共飞ここ 飞保管されて和り，

(1) 長さ標準の設定維持

(2)，長さ標準の供給

（3）工業用標準の精度向上 等を主目的として, これと必要な研究, 検查を行つてい る。 
NBS では一般に戦後外部からの依頼の仕事が多くな り，基礎的な研究に専念することが困難になつてきたの で，数年前にその重点を計量標準执よび測定方法に関す る研究に限定した。他からの依頼の仕事は, その問題が 一般的な科学的価值を有するか, NBS本来の使命に密接 な関係をもつものか，または設備上 NBS しか引受ける ことのできないもののみに応ずる方針となつている。こ の方針により，たとえば第一次大戦のときは168名の人 が一般ゲーシの検查に従事していたが, 現在ではNBSで 行うこの種の仕事はなくなり，主としてマスターゲージ の検査のみとなつたことと，他同様な検查機関が設け られたこと等の理由で, 単に8名の者が従事しているに 過ぎない。

現在最も力を入れている研究はブロックゲージの測定 精度向上飞関するものである。元来ブロックゲージの測 定精度は普通 10-6, すなわち $25 \mathrm{~mm}$ のブロックゲージ は $0.025 \mu$ の精度で測定される。最近の工業の進歩によ り, 特に誘導弾, ジェット機, 工作機械, その他の工業 製品に颃ける部品の寸法精度が極度にやかましくなつた 結果，その管理に必要なブロックゲージに対しては更に 1 けた高い $10^{-7}$ の精度が要求されるに至つている。こ のような工業の実際的立場からの強い要求により, 現在 NBSはこの問題に対し特別の大きな努力を払つている。 これに対し 1957年には次の11の民間会社が NBS に研究 費を払つてその研究推進に協力している。

Dearborn Gage Co.

DoAll Co.

E.I.Du Pont de Nemours \& Co., Inc.

Greenfield Tap and Die Corp.

Hughes Aircraft Co.

International Business Machines Co.

Pratt \& Whitney Co.

Taft-Peirce Foundation.

The Sheffield Corp.

The Van Keuren Co.

Timken Roller Bearing Co.

そしてこれは NBS と対する民間からの依託研究 17 項 目のうちの一つであり，依託機関総数 23のうちの11を占 めていることを考えると, 現在この問題がいかて緊急と されているかを想像できる。

ブロックゲージの 測定精度を1けた上げるためとは， (1) 測定器と測定方法の精度を上げることおよび (2) 更 に安定したブロックゲージ用材料をうることが必要であ る。(1) そ関しては, 先ず標準ブロックゲージと比較测定
できる精密な比較干渉計が試作された。またこれと平行 して第一次標準ブロックゲージの 絶対測定方法を改良し てその精度を上げることも必要である。そのための研究 の一つとして上記の比較干涉計は 更に単色光を用いて絶 対測定を行えるような干涉計に発展させることが考えら れている。また多重反射を利用する特殊な高感度干涉計 そより，ブロックゲージ測定面の位相差を精密に測る研 究を行つている。ブロックゲージの測定方法に関して大 きな問題となるものは密着膜厚の繰返し精度であつて, これも現在密着油としてシリコン油, ケロシン, 防錆油 等を使つた場合および油なしの場合につき実験が進めら れている。次にブロックゲーシの経年変化については, 成分, 熱処理の分つた 19個の鋼製ブロッタゲーシの過去 25年間飞拈ける寸法変化が報告されて打り，これによれ ぼ同じ成分, 熱処理のものでも, 最初少し短くなつてから 安定状態に入るものと, 引続き一定の割合または段々減 少する割合で伸びているものとがある。そしていまだに 伸びているものと安定しているものとについて残留オー ステナイトの率を調べた結果によれば，この経年変化は 明らかに 残留オーステナイトによるるのであることが推 定されている。ブロックゲーシの経年変化はアメリカで も現在大きな問題として研究が進められているが, NBS では冶金部で 200 個のブロックを作り，そのうち同じ成 分のものを 1 組として 11 組作りその安定性とつき研究し ているという。

30in から 80in までの長いゲージの測定精度の国内統 一を図る目的で, NBSでは 3 個の安定なゲージを作つて 先ず同所で測定し，これをアメリカ国内の約 20 社に持廻 つてその測定值を比較している。その結果についてはま だ発表されていない。NBSではこれをブラットの測長機 で, 所定の寸法に組立てられた標準ブロックゲージと比 較している。

ブロックゲージについで NBS 精密測定部門として大 きくとり上げている問題はアメリカ石油協会(American Petroleum Institute 略して API) 規格によるマスタ ーテーパネシゲーシの検查である。これは API 規格の 管等を作つているメーカはそのネシの検査のため必ら ず API 規格のネジ゙ージを持つていなければならない こと，そのマスターゲージ API の指定した各国国立 標準機関の成績書を要することなどが定められており, NBSがアメリカと护けるこの検査機関となつていること そよるものである。たとえば NBS そ括ける 10in 以下 のテーパプラグネジ゙ージの検査精度は, 山の半角が 3' 10', ピッチ, 有効径打よびテーパが $2.5 \mu$, 外径が 
$7.5 \mu$ である。比較的大きなテーパリングネジゲージのピ ッチ誤差やテーパの測定には, 特にこのために設計した 測定装置を使用している（図 1）。これはネシをそのピッ 千線が水平になるようと傾けて，ネシの山をフィーラて 探つていくもので，フィーラの動きは顕微鏡と標準尺て よみとる形式である。フィーラの傾きは電気的インジ 一タで指示される。ネジ山の角は 51 扮さに作られた 角度ゲージをあてて検査する。

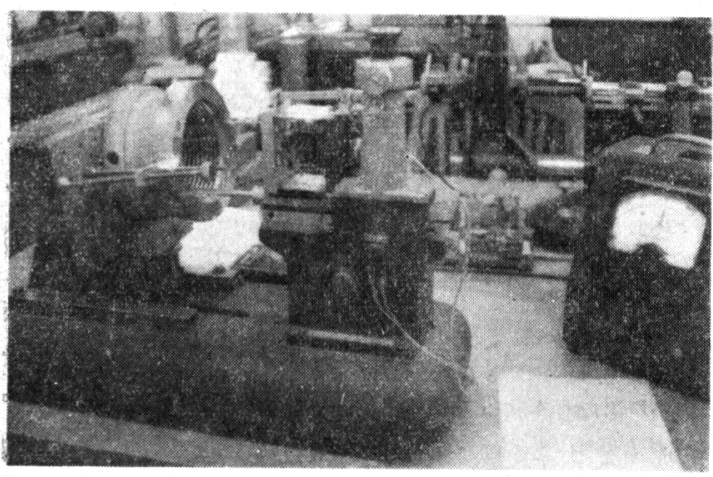

図 1

ネジ測定用針金は非常に精度の高い測定が必要であつ て，各国とも苦心しているが，NBSでは最近測定子の動 きを光波干涉式に測る装置を作つている。測定力は普通 $57 \mathrm{~g}$ であるが，測定力を変えて测ることにより测定力な しのときの值を求めることができる。この装置で鋼球の

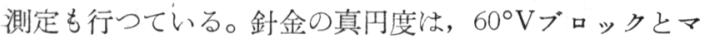
イクロケータで測定される。

ブロックゲージの検查に対しては, 前述のと和り測定 精度を 1 けた上げるための基本的な研究が行われている が，一方飞捈いて検查能率を上げることについても研究 されている。すなわちブロッゲージの両測定面に上下両

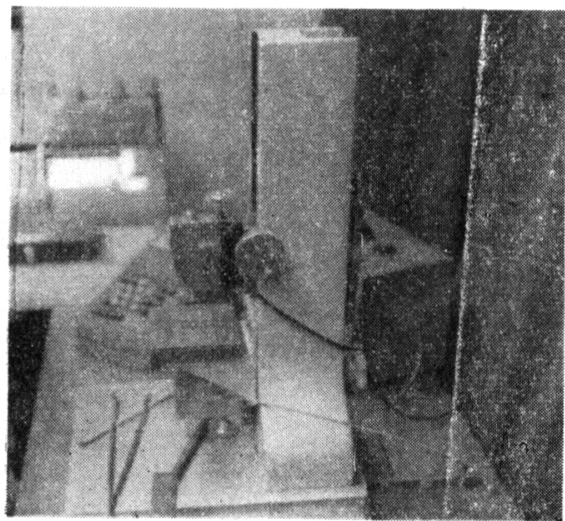

図 2
方向からそれぞれ測定子を接触させて両方の動きをそれ ぞれ電気的に測定するような 測定装置が試作されている （図 2)。測定力は上面に対して下向きに $113 \mathrm{~g}$ ，下面に対 して上向きに $57 \mathrm{~g}$ かかつている。一般のブロックゲージ 検查には NPL 式のヒルガー製干涉計も利用している。

この注か角度ゲーシの測定には，ブロックダージで組 立てられた 24 面のポリゴン鏡とオートコリメータが用意 されて招り,これとより0.2秒の精度がえられるという。

以上の精密測定に関する研究検査にあてられている室 は数個の $20^{\circ} \mathrm{C}$ 恒温室よりなつているが，そのほかに特 飞 $50 \mathrm{~m}$ 巻尺の検査を行うための細長い恒温室も設備され ている。ここでは普通の鋼製巻尺の浪かに精密なアンバ 一製の基準テープも検查される。この場合は測定される テープに $15 \mathrm{~kg}$ の張力をか忛， $5 \mathrm{~m}$ 打きに配置された顕 微鏡で目盛線をよみとる。各顕微鏡の間隔は氷水の槽に 人れられた長方形断面の鋼製 $5 \mathrm{~m}$ 標準尺によつて較正さ れる。測定室は $20 \pm 0.5^{\circ} \mathrm{C}$ に保持されている。テープ の線膨張係数の測定をするとき山, これて電流を流して その電流加ら温度を決定し，そのときのテープの伸びを 顕微鏡でよみとるので，室の温度を変光る手数は不要で ある。

\section{4. 検查精度と手数料}

NBSの精密測定部門が行つている主な検査の検査精度 と手数料を表 2 飞示す。この検査精度によつてアメリカ そ扮ける精密測定の精度の水準を知ることができよう。

表 2

\begin{tabular}{|c|c|c|c|c|}
\hline 品 名 & 大きさ & 項 目 & $\mid \begin{array}{c}\text { |検租精度 } \\
(\mu)\end{array}$ & $\begin{array}{l}\text { 検租手数 } \\
\text { 料 (\$) }\end{array}$ \\
\hline 標 準 尺 & $1 \mathrm{~m}$ & 全 長 & $\begin{array}{r}1 \\
10\end{array}$ & 37 \\
\hline $\begin{array}{l}\text { アンバーテー } \\
\text { プ }\end{array}$ & $50 \mathrm{~m}$ & $\begin{array}{c}\text { 全 長 } \\
\text { 膨張㛊数 }\end{array}$ & $\begin{array}{r}50 \\
1 \times 10^{-6} \\
/ \mathrm{deg} \\
\end{array}$ & $\begin{array}{c}69 \\
140^{1)}\end{array}$ \\
\hline 光 線 定 盤 & $\left|\begin{array}{r}\text { 直径 } 250 \\
\text { mm以下 }\end{array}\right|$ & 平 面 度 & 0.025 & $\left.15 \sim 39^{2}\right)$ \\
\hline \multirow[t]{7}{*}{$\begin{array}{l}\text { フロックゲー } \\
\text { ジ }\end{array}$} & $0.1^{\prime \prime} \sim 1 "$ & & $\begin{array}{l}0.05 \\
0.10\end{array}$ & $\begin{array}{l}4.5 \\
2.75\end{array}$ \\
\hline & $1^{\prime \prime} \sim 2^{\prime \prime}$ & & $\begin{array}{l}0.05 \\
0.13\end{array}$ & $\begin{array}{l}13 \\
10\end{array}$ \\
\hline & $2^{\prime \prime} \sim 3^{\prime \prime}$ & & $\begin{array}{l}0.08 \\
0.15\end{array}$ & $\begin{array}{l}13 \\
10\end{array}$ \\
\hline & $3 \prime \prime \sim 4^{\prime \prime}$ & & $\begin{array}{l}0.10 \\
0.18\end{array}$ & $\begin{array}{l}13 \\
10\end{array}$ \\
\hline & $0.01 " \widetilde{0.09 "}$ & & 0.08 & 3.5 \\
\hline & $4 " \sim 8^{\prime \prime}$ & & $\begin{array}{l}1 \text { "当り } \\
0.025\end{array}$ & 15 \\
\hline & $8^{\prime \prime} \sim 20^{\prime \prime}$ & & II & 23 \\
\hline
\end{tabular}




\begin{tabular}{|c|c|c|c|c|}
\hline 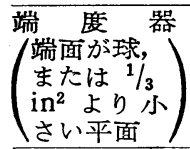 & $\begin{array}{l}\text { 8"以下 } \\
8 " \sim 72 "\end{array}$ & & $\begin{array}{c}1 \\
1 \text { 光当り } \\
1.25\end{array}$ & $\begin{array}{c}12 \\
\left.18 \sim 32^{2}\right)\end{array}$ \\
\hline プラグゲージ & $\begin{array}{l}\text { 2"1以下 } \\
\text { 6" 以下 }\end{array}$ & $\mid \begin{array}{c}\text { 值径, テー } \\
\text { パ，真円度 } \\
\text { J }\end{array}$ & $\begin{array}{l}0.25 \\
0.75\end{array}$ & $\begin{array}{l}18 \\
12\end{array}$ \\
\hline リングゲージ & $\begin{array}{l}1 / 4 \sim 2^{\prime \prime} \\
1 / 4 " \sim 6^{\prime \prime}\end{array}$ & & $\begin{array}{l}0.25 \\
0.75\end{array}$ & $\begin{array}{l}30 \\
15\end{array}$ \\
\hline $\begin{array}{l}\text { 平行ネジプラ } \\
\text { グゲージ }\end{array}$ & 4"'以下 & $\left|\begin{array}{|c|}\text { 山 角 } \\
\text { ピ兴, 有 } \\
\text { 効径 } \\
\text { 外 径 }\end{array}\right|$ & $\left|\begin{array}{c}2^{\prime} \sim 8^{\prime 2} \\
2.5 \\
5\end{array}\right|$ & 15 \\
\hline $\begin{array}{l}\text { 平行ネジリン } \\
\text { グゲージ }\end{array}$ & $3 / 16 \sim 12^{\prime \prime}$ & $\begin{array}{l}\text { 山角 } \\
\text { ピッチ } \\
\text { 内 径 }\end{array}$ & $\mid \begin{array}{c}\left.5 \sim 20^{\prime 3}\right) \\
2.5 \\
5\end{array}$ & 15 \\
\hline $\begin{array}{l}\text { テーパネジプ } \\
\text { ラグゲージ }\end{array}$ & 10"以下 & 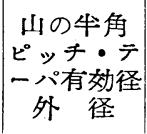 & $\begin{array}{c}3 \sim 10^{\prime} \\
2.5 \\
7.5\end{array}$ & 40 \\
\hline $\begin{array}{l}\text { テーパネジプ } \\
\text { ラグゲージ }\end{array}$ & $10^{\prime \prime} \sim 24^{\prime \prime}$ & 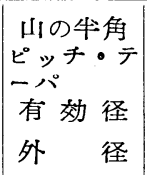 & $\begin{array}{c}\left.3^{\prime} \sim 10^{\prime 3}\right) \\
2.5 \\
5 \\
10\end{array}$ & 50 \\
\hline $\begin{array}{l}\text { テーパネジリ } \\
\text { ングゲージ }\end{array}$ & 24"以下 & $\left|\begin{array}{lll}\text { 山 } & \text { 角 } \\
ヒ^{\circ} & \text { チ } \\
\text { テ } & - & \text { パ } \\
\text { 内 } & \text { 径 } \\
\text { スタン } & \text { ドオ }\end{array}\right|$ & $\begin{array}{c}\left.5^{\prime} \sim 15^{\prime 3}\right) \\
2.5 \\
5 \\
12.5 \\
25\end{array}$ & 30 \\
\hline
\end{tabular}

注 1)この手数料の值には全長の検查も含んでいる。

2) 大きさによつて手数料が異なる。

3）ピッチの大きさによつて検䈏精度が異なる。

\section{5. むすび}

NBSの見学を終え，ふりかえつてわが国の現状と比一 て考劣て見ると，精密測定部門に招いて我々は決して後 れをとつていないと思う。光波干涉を応用する測定の研 究やブロックゲーシの測定技術とついてもまた一般的な 測定設備飞括いてもそういえる。しかし NBSがその長年 の間積み重㸚て来た伝統的な技術とこれを支える 民間工 場研究所の協力炈て, 特江工業と直結する実用的な

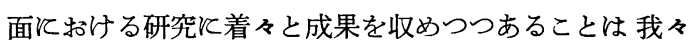
の学ぶべき点である。標準関する基礎的な研究はもち 論重要であるが，これを工業方面からの要求に応じて必 要な精度で流して行くことすなわち標準の供給が円滑、 行われなけれげ折角の基礎研究も埋れてしまうわけであ る。そしてこの標準の供給の仕事に対し，アメリカでは NBSのほか飞立派な民間検查機関があつて，この仕事の 一部を引受けている。これらの検査機関の設立に際して はNBS色々な技術的援助を行い，その後も緊密な技術 的連絡をとつているようである。その 1 例は Sheffield 社のEli Whitney Laboratory である。NBSを中心と したこのようなアメリカ国内の長さの統一飞関する仕事 はわが国でも大い参考として学ぶ必要があるう。

\section{参考文献}

1) Annual Report 1957, NBS.

2) Metrology of Gage Blocks, NBS Circular 581 (1957).

3) Test Fee Schedules of the NBS (Reprinted from "Federal Register" March 30, 1956... Vol. 21, No, 62).

\section{朝日科学奨励会応募者推鷹}

朝日新聞社より例年行われる 奨励金応募者の推薦を依 頼して来ると予定されるので, 本会では一般会員よりの 応募を 2 月末日本会必着飞て受付け, 3 月理事会で推薦
致すことに決定しました。御希望の方は朝日新聞社の書 式による書類（その中本会長の氏名の所は書かない）と 推薦決定の参考々なる資料をつけ, 本会事務所宛招送り 下さい。期日飞遅れたものは推鷹対象から除かれますか ら扮含み置き下さい。 